\title{
The Question of Global Society in Post-Corona Time: Towards a Paradigm Shift
}

\author{
Mostafa Norouzi ${ }^{1} \cdot$ Mahsa Hashemi ${ }^{2} \cdot$ Zahra Pouri $^{3}$
}

Received: 28 June 2020 / Accepted: 28 June 2021 / Published online: 29 July 2021

(c) The Author(s), under exclusive licence to Springer Nature Switzerland AG 2021

\begin{abstract}
Whether the COVID-19 has natural or laboratory roots, it has so far posed serious challenges for many of the current human paradigms and the longer it takes, the greater impacts it will have on today's world order. This paradigm shift and a new sight at the post-Corona era led us to the question of which factors caused the epidemic to spread more or less indifferent countries of the world and what was the global responses to prevent this epidemic? Following that, what is important, is the consequences of this epidemic, which can be considered in the question of a paradigm shift in the post-Corona time.
\end{abstract}

Keywords COVID-19 - Global society $\cdot$ Economic crisis $\cdot$ Paradigm shift $\cdot$ Postcorona time

\section{COVID-19 and Global Society's Responses}

Between 1940 and 2014, 335 infectious and contagious diseases were reported, most of which had severe effects on global health and the economy (Tabish, 2020). The outbreak new type of Coronavirus (COVID-19) in January in Wuhan, China spread around the world in less than three months and disrupted the two key systems of economy and global security. Because China has always been recognized in most sections as an integral part of the global economy (Sohrabi et al., 2020; Zaman

Mostafa Norouzi

norouzi.m60@gmail.com

Mahsa Hashemi

mahsa.hashemi@ut.ac.ir

Zahra Pouri

z.pouri@binaloud.ac.ir

1 Geography and Urban Planning, Tarbiat Modares University, Tehran, Iran

2 Architecture and Urbanism, University of Tehran, Tehran, Iran

3 Tourism Management, Binaloud Institute of Higher Education, Torqabeh, Iran 
et al., 2020). In fact, the different dimensions of the COVID-19 crisis have revealed new insight about the extent and depth of the inefficiency of various dimensions of global development management; such that contrary to most other crises and mass damages, the epidemic's fatalities and financial losses have spread around the world. Countries with the highest economic growth and development, such as the United States, China, Italy, Spain, the United Kingdom, and Brazil, were just as struggling to cope with epidemic shock as the less developed countries. In other words, the outbreak of COVID-19 has eroded the meaning of weak and strong in the world order and has shown how vulnerable countries can be.

Now the question is that what these countries had in common that surprised them. In answering this question, we can bring examples and evidence from global reactions to the COVID-19 pandemic, because governments' strategies for coping with this crisis have played a fundamental role. Some developed countries have handled it well. On a smaller scale, in western democracies, which nevertheless we expect more of them, managed to reduce the mortal effects of this disease, because the remnants of the welfare society exist much more in countries such as Scandinavia, Germany, and Austria as well as they followed expert knowledge and reacted timely to the outbreak of the disease. The Scandinavian countries are almost identical in terms of economic indices and they are not much different from the other developed European countries and the US which has suffered the most. the US has not done well with handling the virus and has a higher rate of infection than almost any other country. Developed European and main tourist countries such as Spain, Italy, and France did not take the danger seriously in time and did not quarantine the cities in time (Gossling et al., 2020; Rudan, 2020). Hence, the spread of the virus became out of control, so that the British Prime Minister, Boris Johnson, contracted the disease because he did not take the risk seriously. Similarly, the slowdown and delay in the public announcement of this epidemic in Iran, and the subsequent travels of the Iranians during the New Year holidays made Iran one of the countries with the highest number of infected cases (Raoofi et al., 2020; Wikipedia, 2020). In Brazil, the right-wing President, Jair Bolsonaro, called the COVID-19 a "fantasy" and told in response to journalist's question: "So what? What do you want me to do?" (The Lancet, 2020) Despite initial warnings, instead of planning an emergency, the US President, Donald Trump, called the virus a lie and an election hoax by the Democratic Party after the Russia investigation (Strauss \& Laughland, 2020; The New York Times, 2020). While India, with a population of around 1.3 billion, with an estimated per capita income of one-tenth of the United States, has about 236,657 cases, and only 6649 deaths (by the 5th of June) (JHU CSSE, 2020). In an opinion piece entitled "Why does India have so few COVID-19 cases and deaths?" Malani et al. (2020) point to four factors: 1. The epidemic may have struck later than in other countries; 2 . The Indian government announced a 21-day lockdown and physical distancing; 3. The published statistics may not be accurate and 4. Widespread vaccination for tuberculosis and malaria in India has made people resistant to the virus. Despite these experiences, the puzzle of Africa is still unanswered. But, the antibody from the Ebola vaccination epidemic, along with experience in how to manage and fight epidemic disease, may have helped the African people resist the 
COVID-19 epidemic. There are also fewer tourist and commercial visits to the African continent.

\section{Why Global Society Need to a Paradigm Shift?}

Unlike many crises, COVID-19 disease is not merely a local, national, or regional crisis, but a global crisis that each country responds to in its own language, and in return for this response, the aftermath must be expected. In the previous section, we discussed global responses to the epidemic. These reactions to the health shock are pivotal so that they give us a clear trajectory to the current section. However, here the important point is the repercussion of this epidemic, which arises from the former section and manifests itself in the second and preponderant question that comes to mind. What economic and political pattern will this virus follow? The answer to this question also leads us to the important principle in the field of health that most health issues have both a health aspect and a socio-economic aspect in the sense that the disease is not merely limited to physiological, bacterial, and microbial conditions. Since the epidemic has so rapidly affected most countries in the world, the governments' response to the COVID-19 is more focused on general health crisis than on economic crisis. There is no doubt that the COVID-19 crisis will overshadow the world economy and lead to a reduction in Gross Domestic Product. Therefore, we should expect an increased global recession and reduced economic growth, which among its early effects can be made to the spread of unemployment, the fall in oil prices and the crisis at the corporate level. However, the worth considering is the consequences of this disease in the post-Corona era. Most articles (See, e.g. Alon, 2020; Chohan, 2020; Gruszczynski, 2020; Kuentak, 2020; Paul et al., 2020; Tabish, 2020; WEF, 2020) which have been recently written about the "Post-Corona era", has focused on general topics such as strengthening nationalism, weakening liberalism and globalization, accelerating the decline of US power, new global polarization and further promoting China's position, increasing the number of bankrupt governments, the continuation of oil and energy-reduced prices, huge losses of oil-producing countries, increased waves of unemployment, pressure on social welfare funds, fundamental changes in businesses and the quantity and quality of human resources, the growth of remote labor market, and online purchases and have dealt with these aspects.

The global outbreak of COVID-19 and its various butterfly effects have resulted in interest in the state and public services and rebuilding the world's economy in order to more justice distribution, as the world economy has been unfair in recent years and income inequality has been increasing sharply (Cotula \& Schwartz, 2020; Michelson, 2020; Politico, 2020; Zaman et al., 2020). These conditions have shown that the dominant economic paradigm cannot respond appropriately to crises and as a result, global structures and institutions are affected by this problem, as the World Trade Organization failed to play its leading role in this difficult time. There is a kind of debate here that needs to pay more attention to social values, identity, and sustainable human development along with issues such as security, production, finance, and knowledge, and the geographical boundaries, 
the network economy, and global communications let's be a little more limited. In fact, in post-Corona world, nationalism represents an opposed desire to globalization, which creates a differentiated understanding of the new spatial governance and territorialism (Chomsky, 2020; Fukuyama, 2020; Harari, 2020). This paradigm shift, especially in the age of globalization can establish its dominance in the economic, social, and political system. This is where a paradigm shift is best understood, as Holemans (2020) emphasized the matter of the paradigm shift: 'from a sleepwalking society focused on profit, competition, and consumption, to a future-oriented one that prioritizes investment, cooperation, and wellbeing'. However, the epidemic is not the basis of this insight. It just reiterated this need, as several studies referred before the onset of COVID-19 time (Horner, 2020; Laybourn-Langton \& Jacobs, 2018). The need for a new paradigm is essential, because as Horner (2020) argued the current global development is very ill-fitted and uneven, and characterized by interconnected neoliberal capitalism, the challenge of sustainability, as well as the blurring of North-South boundaries. This is a sign of the deteriorating situation in the world's dominant paradigm, which has begun before the COVID-19 crisis; however, with the arrival of the uninvited guest in the whole world, this need for change has become more obvious.

How the post-Corona world will really be? It is a question that many of us are interested in finding answers. It may be a little early to say that COVID-19 will mark another turning point, as it did in the 1930s, and the fate of one-term presidency of Hoover will be repeated for Trump. As time passes on and the crisis gets longer and longer, it can give us a clearer and more analytical perspective. Global society did not learn from Ebola when in 2015, the G7 members proclaimed it as a 'wake-up call' for better global cooperation (Paul et al., 2020). Now, in the COVID-19 lived experience, it is time to reveal and doing comprehensive analysis, systematic and applied research in the field of social justice, and move toward efficient governance. Meanwhile, any country that has stronger governance and has already been able to conserve the necessary resources has now been able to do better against the COVID-19 crisis or as Harari (2020) highlighted 'this storm will pass, but the choices we make now could change our lives for years to come'. It seems that global societies now have two options, either to isolate themselves or to work together to solve problems globally and it seems that they have to choose the second way.

\section{Declaration}

Conflict of Interests The author(s) declared no potential conflicts of interest with respect to the research, authorship, and/or publication of this article.

\section{References}

Alon, I. (2020). COVID-19 and international business: A viewpoint. FIIB Business Review. https://doi. org/10.1177/2319714520923579

Baker, P., \& Karni, A. (2020). Trump accuses media and democrats of exaggerating coronavirus threat. The New York Times, 28 February. 
Chohan, U. W. (2020). A post-coronavirus world: 7 points of discussion for a new political economy. CASS Working Papers on Economics \& National Affairs No. EC015UC. Available at: https://ssrn. com/abstract=3557738 or https://doi.org/10.2139/ssrn.3557738. Accessed 23 Apr 2020

Chomsky, N. Noam Chomsky: 'Coronavirus pandemic could have been prevented', Aljazeera, April 3, 2020.

Cotula, L., \& Schwartz, B. (2020). COVID-19 and global economic ordering: Radical shift or more of the same? In: International Institute for Environment and Development. Available at: https://www.iied. org/covid-19-global-economic-ordering-radical-shift-or-more-same. Accessed 8 May 2020

Fukuyama, F. Francis Fukuyama on coronavirus and the crisis of trust. Financial Times (audio file by Gideon Rachman). April 16, 2020.

Gossling, S., Scott, D., \& Hall, C. M. (2020). Pandemics, tourism and global change: A rapid assessment of COVID-19. Journal of Sustainable Tourism. https://doi.org/10.1080/09669582.2020.1758708.

Gruszczynski, L. (2020). The COVID-19 pandemic and international trade: Temporary turbulence or paradigm shift? European Journal of Risk Regulation, 11(2), 337-342. https://doi.org/10.1017/err. 2020.29

Harari, Y. N. (2020). The world after coronavirus. Financial Times. 20 March.

Holemans, D. (2020). Resilience under shock: Time for a paradigm shift. Green European Journal. 16 April.

Horner, A. (2020). Towards a new paradigm of global development? Beyond the limits of international development. Progress in Human Geography, 44(3), 415-436. https://doi.org/10.1177/0309132519 836158

Johns Hopkins University CSSE (2020). COVID-19 Dashboard. Baltimore: Johns Hopkins University. https://coronavirus.jhu.edu/. Accessed 5 June 2020

Kuentak, P. (2020). Pandemic paradigm shift. Bangkok Post. 27 April.

Laybourn-Langton, L., \& Jacobs, M. (2018). Paradigm shifts in economic theory and policy. Intereconomics, 53, 113-118. https://doi.org/10.1007/s10272-018-0737-4

Malani, A., Gupta, A., \& Abraham, R. (2020). Why does India have so few Covid-19 cases and deaths? Quartz India. Available at: https://qz.com/india/1839018/why-does-india-have-so-few-coronaviruscovid-19-cases-and-deaths/. Accessed 25 Apr 2020

Paul, E., Brown, G. W., \& Ridde, V. (2020). COVID-19: Time for a paradigm shift in the nexus between local, national, and global health. BMJ Global Health, 5, e002622. https://doi.org/10.1136/ bmjgh-2020-002622

Raoofi, A., Takian, A., \& Akbari Sari, A. (2020). COVID-19 pandemic and comparative health policy learning in Iran. Archives of Iranian Medicine, 23(4), 220-234. https://doi.org/10.34172/aim.2020. 02

Rudan, I. (2020). A cascade of causes that led to the COV I D -19 tragedy in Italy and in other European Union countries. Journal of Global Health, 10(1), 010335.

Sohrabi, C., Alsafi, Z., O'Neill, N., et al. (2020). World Health Organization declares global emergency: A review of the 2019 novel coronavirus (COVID-19). International Journal of Surgery, 76, 71-76. https://doi.org/10.1016/j.ijsu.2020.02.034

Strauss, D. \& Laughland, O. (2020). Trump calls coronavirus criticism Democrats' 'new hoax' and links it to immigration. The Guardian, 29 February.

Tabish, S. A. (2020). COVID 19: The worst health calamity of the world. Indian Journal of Scientific Research, 9(4), 1-4. https://doi.org/10.36106/ijsr

The Lancet (2020). Editorial, COVID-19 in Brazil: "So what?" 395(10235): 1461.

Wikipedia (2020). Coronavirus outbreak in Iran. Available at: https://en.wikipedia.org/wiki/2020_coron avirus_outbreak_in_Iran. Accessed 18 Apr 2020

World Economic Forum (2020). The post-COVID-19 world could be less global and less urban. Available at: https://www.weforum.org/agenda/2020/05/coronavirus-covid19-urbanization-globalizationchange/. Accessed 2 June 2020

Zaman, K. T., Islam, H., Khan, A. N., et al. (2020). COVID-19 pandemic burden on global economy: A paradigm shift. Preprints. 2020050461. https://doi.org/10.20944/preprints202005.0461.v1

Publisher's Note Springer Nature remains neutral with regard to jurisdictional claims in published maps and institutional affiliations. 